\title{
Osteosarkom, malign fibröz histiyositom - klinik radyoloji, patoloji ve tedavi stratejileri
}

\author{
Osteosarcoma, malignant fibrous histiocytoma - \\ clinical radiology, pathology and treatment strategies
}

\author{
Murat Hız \\ İstanbul Üniversitesi Cerrahpaşa Tıp Fakültesi, Ortopedi ve Travmatoloji Anabilim Dalı, İstanbul
}

\begin{abstract}
Osteosarkom multipl miyelomdan sonra en sık görülen habis kemik tümörüdür. En sık ikinci dekadda görülür. Adolesanların özellikle diz çevresi gibi major eklemlere komşu ağrılarında, aksi kanıtlanana kadar, osteosarkom olasılığı akılda tutulmalı ve iki yönlü direkt grafi ile başlayarak yeterli görüntüleme yapılmalıdır. Kesin tanı biyopsi ile konur. BT yardımlı kesici iğne biyopsileri ve gerekirse insizyonel biyopsi, esas ameliyat insizyonun trasesinde yapılmalıdır. Seçkin tedavi yöntemi, neoadjuvant kemoterapi ve ekstremite koruyucu tedavidir. Düşük nekroz oranı, lokal nüks, kontamine cerrahi sınır, negatif prognostik etmenlerdir. Multidisipliner tedavi ile beş yıllık hastalıksız sağkalım \%65 düzeyindedir. Ameliyat sonrasında sistemik metastazlar açısından olgular en az beş yıl takip edilmelidir. Erken tanı, düşük tümör volümü önemli olmakla beraber, tedavide belirleyici etmen tümörün sistemik tedaviye verdiği yanıt ve en az geniş eksizyon tarzında tümörsüz sınırdır. Akciğer metastazlarında metastazektomi düşünülmelidir.
\end{abstract}

Malign fibröz histiyositom, kollajen üreten indiferansiye iğsi hücrelerden oluşan nadir görülen bir tümördür. Yumuşak dokuların malign fibröz histiyositomunun kemik orijinli bir varyantı olarak düşünülebilir; WHO yeni sınıflamasında bu tümörlerin indiferansiye yüksek gradeli pleomorfik sarkom olarak nitelendirmektedir. Primer ve sekonder olabilir. Klinik davranışı osteosarkoma benzer ve tedavisi osteosarkom gibi yapılır. Neoadjuvant kemoterapi ve ekstremite koruyucu cerrahi tedavi, lokal rezeksiyon + rekonstrüksiyon tercih edilen tedavi yöntemidir.

Anahtar sözcükler: malign fibröz histiyositom; indiferansiye yüksek gradeli pleomorfik sarkom; osteosarkom; neoadjuvant tedavi; kemoterapi, adjuvan; ekstremite kurtarma; cerrahi
Osteosarcoma is the second most frequent malignant bone tumour after multipl myeloma. Peak age is the second decade. Adolescents with severe pain occuring near a major joint such as knee should be regarded as having osteosarcoma unless proven otherwise. In such a condition, two plane plain X-ray and necessary imaging should be undertaken. Definitive diagnosis would be reached by biopsy. CT guided cutting nail biopsy or incisional biopsy should be performed on the planned incision line. Neoadjuvant chemotheraphy and subsequent limb salvage surgery is the preferred treatment method. Low necrosis rate, local recurrence, contaminated surgical margin are the negative prognostic factors. Five years of disease free survival with multidiciplinary approach is $65 \%$. Patients should be followed up at least five years for probable systemic metastasis. The most predictive factors of treatment are chemotheraphy response of the tumour, and tumour free margins provided by wide resection besides early diagnosis and low tumour volume. Metastasectomy should be regarded in the presence and progression of lung metastasis.

Malignant fibrous histiocytoma of bone is a rare malignant tumor of bone consisted of collagen forming indifferentiated spindle cells. It may be regarded as a bony variant of malignant fibrous histiocytoma of soft tissues. Malignant fibrous histiocytoma of bone has been classified as undifferantiated high grade pleomorphic sarcoma in the last WHO classification. It may be primary or secondary. Clinical behaviour represents osteosarcoma and treated by means of osteosarcoma treatment. Neoadjuvant chemotherapy and limb salvage surgery, local wide excision and reconstruction is the preferred method of treatment.

Key words: malignant fibrous histiocytoma; undifferentiated high grade pleomorphic sarcoma; osteosarcoma; neoadjuvant theraphy; chemotheraphy, adjuvant; limb salvage; surgery

\section{OSTEOSARKOM}

Multipl miyelomdan sonra kemiğin ikinci en sık görülen habis tümörüdür. Osteoid madde oluşturma eğilimindeki malign mezenkimal hücrelerden oluşur. Neoplastik kemik yapımı bol olmakla beraber, tek bir

büyütmede bile osteoid madde yapımı ve atipik osteoblast varlığı tanı koydurucudur. Sarkomatöz doku osteoblastik, kondroblastik ve fibroblastik diferansiyasyon gösterebilir. ${ }^{[1]}$

- Illetişim adresi: Prof. Dr. Murat Hız, İstanbul Üniversitesi Cerrahpaşa Tıp Fakültesi Ortopedi ve Travmatoloji Anabilim Dalı, Fatih, İstanbul Tel: 0532 - 2347601 e-posta:vmmhiz@yahoo.com

- Gelis tarihi: 17 Haziran 2014 Kabul tarihi: 17 Haziran 2014 


\section{Sıklık}

Tüm organ kanserlerinin \%0,2'sini habis tümörlerinin \%20'sini oluşturur. Her yıl bir milyon nüfusta ortalama 2-3 yeni olgu görülür. ${ }^{[2]}$

\section{Yaş ve cins tutulumu}

Erkek kadın oranı 1,5:1'dir. Her yaşta görülebilmekle beraber ilk iki dekadda tepe yapar. Sıklıkla adolesanların bir hastalığıdır. Dördüncü dekaddan itibaren özellikle sekonder osteosarkom olarak Paget hastalığı, kemik nekrozu ve irradyasyona bağlı olarak göreceli bir artış görülür.

\section{Lokalizasyon}

Her kemikte görülebilmekle birlikte en sık uzun kemiklerin metafizer bölgesini tutar. Olguların $2 / 3$ 'ü, diz çevresi uzun kemikleri olan distal femur, proksimal tibia ve proksimal fibulada görülür. Bunları proksimal humerus ve proksimal femur takip eder. Aksiyel iskelette, vertebra, pelvis ve skapulada nadirdir.

\section{Kilinik bulgu ve semptomlar}

Klasik senaryo, aktif bir adolesanın major bir eklemine (sıklıkla diz çevresi) komşu şiddetli bir ağrı ve
1-2 ay içinde beliren metafizer bir şişlik gelişimidir (Şekil 1). Ağrı delici, batıcı karakterde ve gece artma eğilimindedir. Konvansiyonel analjeziklerle azalır; ancak, tam olarak geçmez. Olguların \%5'inde ilk semptom patolojik kırık olabilir. Hastada hipokrom anemi, sedimentasyon ve alkali fosfataz enzim yüksekliği bulunur. Ağrı, tümör kemik içinde oluşmaya başladığında henüz intrakompartmantal iken oluşan değerli bir semptom olmakla beraber, genellikle bu safhada travmatik ağrı, büyüme ağrısı veya romatizma olarak değerlendirilerek, bazen aile bazen de ilk gören hekim tarafından yeterince dikkate alınmayabilir. Bu nedenle olguların çoğunluğunda tümörün korteksi aşarak yumuşak doku kitlesi oluşturmasından yani ekstrakompartmantal olmasından sonra tanı konur. Bu yanılgılara düşmemek için, özellikle adolesanlarda, major bir ekleme komşu ciddi bir ağrı varsa, aksi ispat edilene kadar habis bir kemik tümörü varlığından şüphelenilerek, tüm kemiğin anteroposterior ve lateral iki yönlü grafilerinin çekilmesiyle başlayan görüntülemeye başvurarak ağrının nedeni araştırılmalıdır. Osteosarkom teşhis edildiğinde sistemik bir hastalıktır. Dolaşan kanda tümör hücreleri mevcuttur ve akciğerlerde tömür mikrometastazları olasıdır. Olguların $\% 5^{\prime} i$ ilk başvuruda akciğer metastazı ile gelebilir. ${ }^{[3]}$

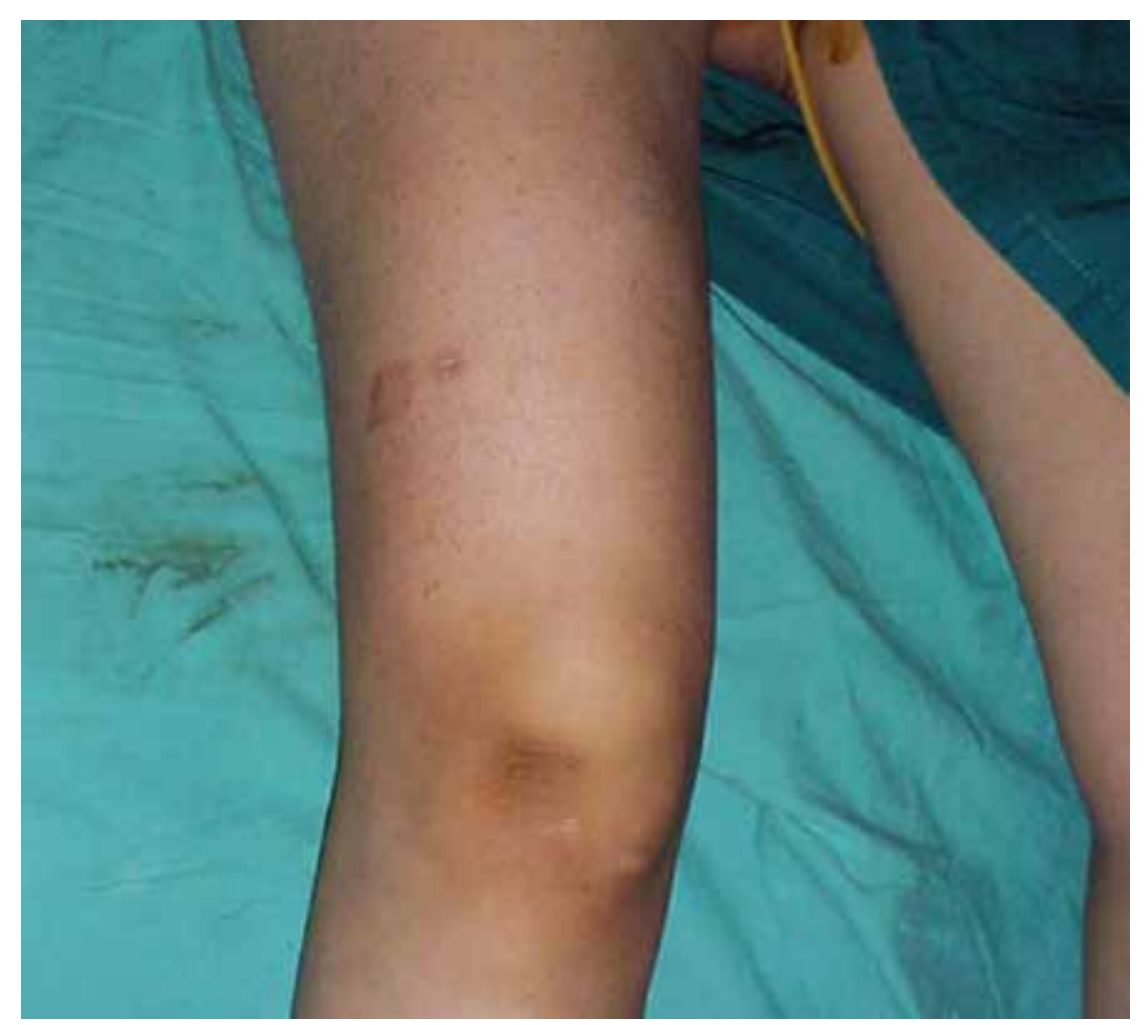

Şekil 1. Hasta görüntüsü: distal femur osteosarkom yumuşak doku şişliği ve tru-cut biyopsi giriş deliği. 


\section{Radyolojik bulgular ve görüntüleme}

Osteosarkom görüntülemesi öncelikle direkt röntgen ile başlamalıdır. Ağrılı kemik birbirine dik iki planda (sıklıkla anteroposterior ve lateral) görüntülenmelidir. Grafide korteks destrüksiyonu, güneş ışığı tarzında periost reaksiyonu, Codman üçgeni, artmış kemik çevresi yumuşak doku gölgesi, coğrafi veya güve yeniği tarzında medüller lezyonlar genellikle major bir uzun kemik metafizinde lokalize olarak, tek tek veya birlikte görülebilir (Şekil 2). Görüntüleme sırası direkt grafi, 3-fazlı dinamik tüm vücut kemik sintigrafisi, manyetik rezonans (MR), bilgisayarlı tomografi (BT), pozitron emisyon tomografi (PET) şeklinde olabilir. Sintigrafide, direkt grafideki lezyonun osteoblastik aktivitesi, aynı kemikteki skip metastazlar ve iskeletteki kemik metastazları ortaya konur. T1 hipoT2 hiperintens görünen kitlenin etrafındaki reaktif zon, epifiz plağı, eklem ve çevre damar sinir paketi ile komşuluk ilişkisi MR'de iyi değerlendirilebilir. Ayrıca, indüksiyon kemoterapisine tümörün verdiği yanıt ve reaktif zonda gelişen fibrözis, sınırlanma ve tümörün mineralizasyonu ile rezeksiyon sınırı belirlenmesinde değerli bilgilere dinamik MR ile ulaşılır. MR, ayrıca, skip metastazların değerlendirilmesi için tüm kemiği görüntüleyecek biçimde çekilir. BT, MR öncesi çok kullanılmış iken bugün radyasyon tehlikesi nedeniyle ancak parosteal sarkom veya periosteal osteosarkom gibi tümörlerde korteks invazyonu hakkında ayrıntılı bilgi edinmek amacı ile kullanılmaktadır. Akciğer metastazının varlığının araştırılmasında ve takiplerinde ise akciğerin kontrastlı ince kesit kalınlığında çekilen BT'si altın standart olma özelliğini korumaktadır. PET-BT, osteosarkom tedavisinde kemoterapi yanıtının değerlendirilmesi ve tüm vücut metastazlarını gösterebilmesi açısından değerli olmakla beraber henüz yaygınlık kazanmamıştır. ${ }^{[2]}$

\section{Biyopsi}

Anamnez, klinik muayene ve görüntüleme sonucunda osteosarkomdan şüphelenildiğinde kesin tanı biyopsi ile konur. Biyopsi, tercihen, hastanın kesin tedavisini yapacak ekip tarafından yapılmalıdır. Biyopsi, ince iğne aspirasyon biyopsisi ve kesici iğne biyopsisi, insizyonel biyopsi şeklinde yapılabilir. Bugün skopi, ultrasonografi (US) veya BT eşliğinde tümörün semi-invaziv kesici iğne biyopsisi ve ince iğne aspirasyon biyopsisi, \%95 doğruluk payı ile, deneyimli patologların elinde ve multidisipliner tümör konseyleri desteği ile olguların
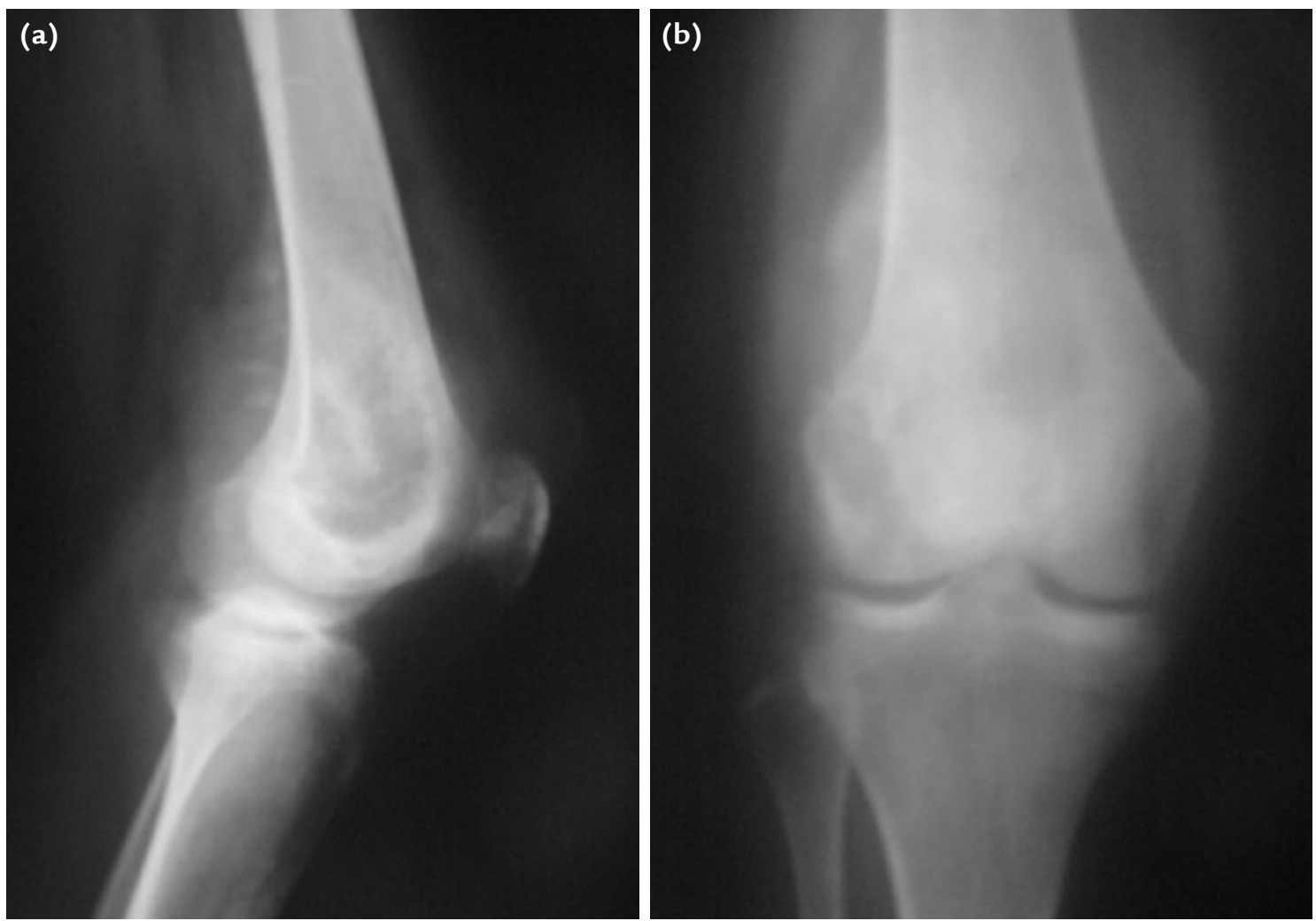

Şekil 2. a, b. Distal femur osteosarkom 14/K. AP (a) ve lateral (b) grafi. 
çoğunda histopatolojik tanıya varmayı sağlamaktadır (Şekil 3). İnce iğne aspirasyon biyopsisi ile kesici iğne biyopsisini aynı giriş deliğinden birlikte yapmak, hem sitolojik özellikler ve hem de matriks konusunda yeterli bilgiye ulaşmayı kolaylaştırır. Kesici iğne giriş deliği, esas ameliyatta eksize edilebilmesi için, biyopsi esnasında mutlaka işaretlenmelidir. Kesici iğne (tru-cut) biyopsisi ile sonuç alınamayan olgularda, ekstremitenin uzun eksenine paralel sonraki ameliyat insizyonu trasesinde yapılan keskin diseksiyonla, kompartman bulaştırması yapmadan, usulüne uygun insizyonel biyopsiler ile yeterli doku alınarak histopatolojik tanıya varmak mümkün olur (Şekil 4). Biyopsi örneği asla ikiye bölünerek ayrı patologlara gönderilmemelidir. Parça, eğer aynı ameliyathane kompleksinde patoloji laboratuvarı varsa ve derhal bakılabilecekse biyopsi kutusu içinde taze olarak gönderilebilirse de bu olanağın bulunmadığı yerlerde \%10 formalin solüsyonunda fikse edilerek gönderilir. Patolojiye, hastanın ismi, protokol numarası, yaşı, cinsi, parçanın alındığı yer, klinik ön tanı gibi bilgileri içeren patoloji istek formu ve lezyonun bulunduğu kemiğin iki yönlü direkt grafisi, parça ile beraber gönderilmelidir. İdeal olan, osteosarkom düşünülen olgunun biyopsi öncesinde tedavisini üstlenecek kapasiteye sahip kurumun kas iskelet sistemi tümörleri konseyinde ortopedist, radyolog, patolog, medikal onkolog ve radyasyon onkoloğundan oluşan bir grup tarafindan, biyopsi yeri ve tipi de dahil olmak üzere, değerlendirilmesi ve böylece tanıya süratle varılmasıdır.

\section{Histopatolojik tipler}

Histopatolojik özelliklerine göre osteosarkom Dünya Sağlık Örgütü (WHO) tarafından şu şekilde sınıflandırılmaktadır. ${ }^{[2]}$

- Klasik (Konvansiyonel) Osteosarkoma (OS)

* Kondroblastik

* Fibroblastik

* Osteoblastik

* Nadir histolojik formlar

- Sklerozan OS

- Osteoblastomayı andıran OS

- Kondromiksoid fibromayı andıran OS

- Kondroblastomayı andıran OS

- Berrak hücreli OS

- MFH'e benzeyen OS

- Dev hücrelerden zengin OS

- Epiteloid OS
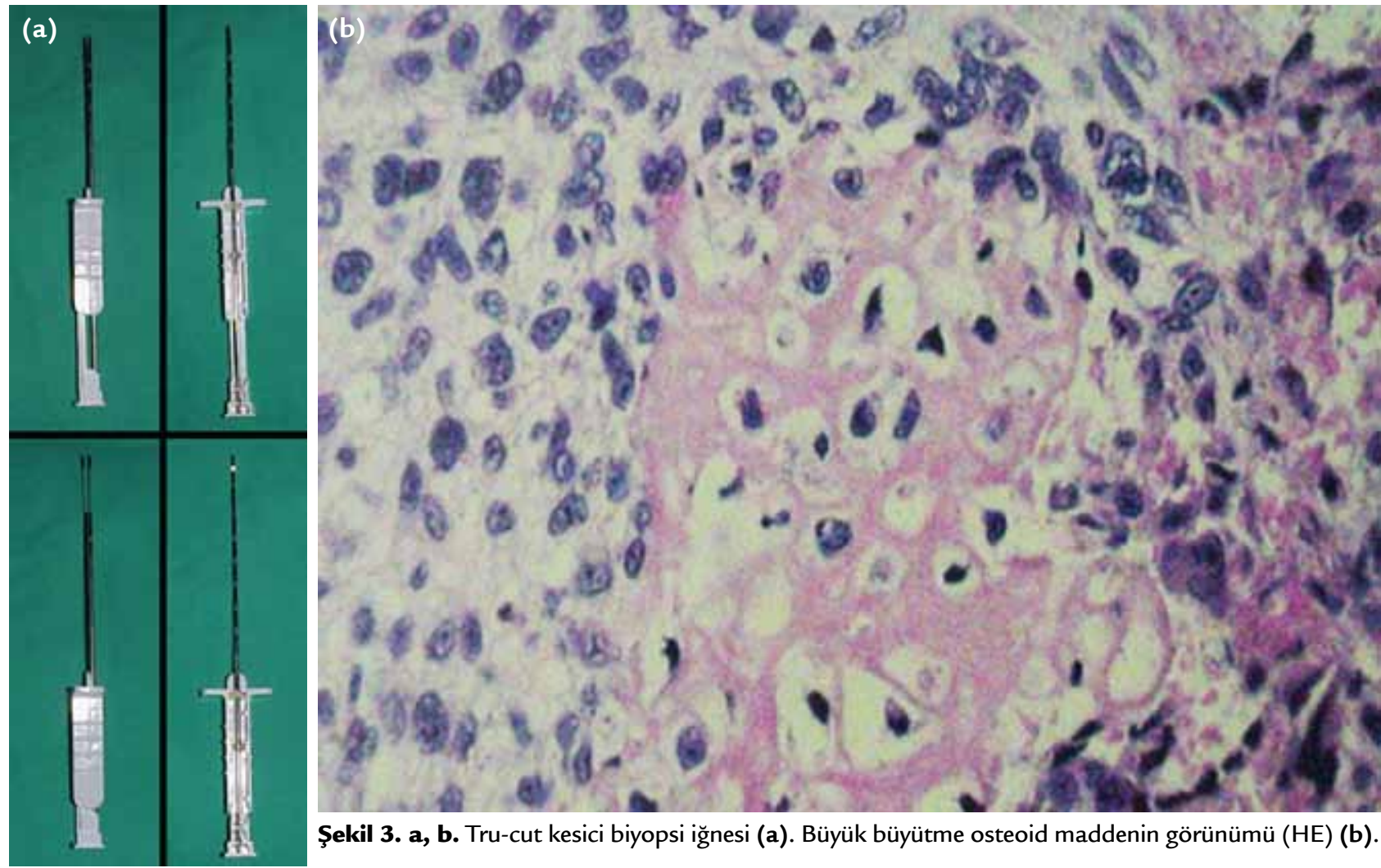

Şekil 3. a, b. Tru-cut kesici biyopsi iğnesi (a). Büyük büyütme osteoid maddenin görünümü (HE) (b). 
- Talenjiektatik OS

- Küçük hücreli OS

- Düşük gradlı santral OS

- Sekonder OS

- Parosteal OS

- Periosteal OS

- Yüksek gradlı yüzey OS

Bu sınıflandırmadan da anlaşılacağı gibi, patoloğun osteosarkom tanısına varması için kemik tümörlerinde deneyimli olması gerekmektedir. Ancak, en sık klasik osteosarkom ve varyantları görülmektedir. Hücresel değişikliğe rağmen tümör osteoid maddesinin veya malign hücreler tarafından tümöral kemik yapımının görülmesi, ortak bir özellik olarak tanı koydurucudur. Hematoksilen-eosin boyası ile osteoid hücreler arasında pembe (eozinofilik) boyanan amorf ve yoğun bir materyal şeklinde görülür. Kollajen, fibrin ve amiloidden ayırt edilmelidir. Osteosarkom hücresellik, hücresel atipi, nükleer pleomorfizm ve mitotik aktivitesine göre düşük ve yüksek gradlı olarak sınıflandırılır. Genellikle kullanılan üç gradlı bir sistemdir. ${ }^{[1,2]}$ Bu sistem tümörün malignitesini değerlendirir.

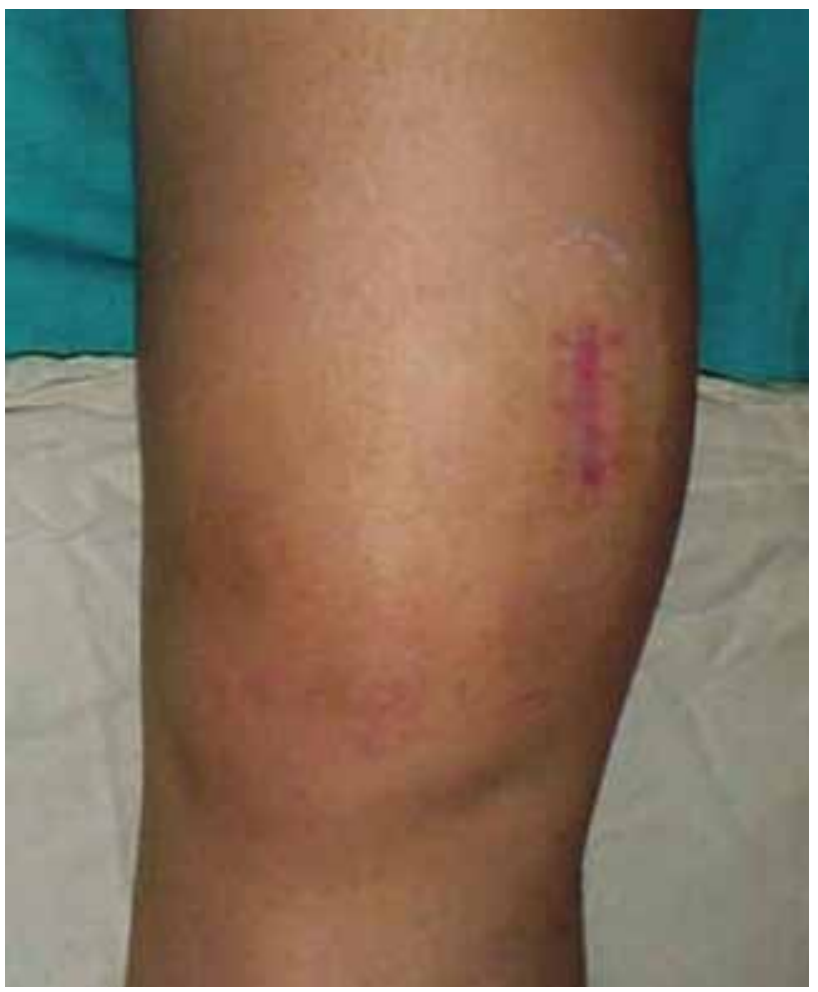

Şekil 4. Biyopsi insizyonu: Uzun eksene paralel, definitif ameliyat insizyonu trasesinde.
- Üç gradlı sistem:

* Grad 1: Düşük, iyi diferansiye

* Grad 2: Yüksek, orta derecede diferansiye

* Grad 3: Yüksek, indiferansiye

Tümörün gradı düşük ise kemoterapi ve radyoterapiye dirençli, yüksek ise adjuvant tedaviye duyarlı olduğu anlamına gelir. Düşük gradlı osteosarkomlarda tek tedavi modalitesi cerrahidir.

\section{Etiyoloji}

Osteosarkomların etiyolojisi henüz bilinmemektedir. Bu nedenle primer osteosarkom olarak adlandırılırlar. Ancak Paget hastalığı, irradyasyon, kemik enfarktı; fibröz displaziye sekonder gelişenler ise sekonder osteosarkom olarak nitelenir. Birçok osteosarkomda supresor genlerinin inaktivasyonu RBI, TP53 gibi onkojenlerin artmış varlığı görülür. Bu onkojenler hücre siklusunun bozulmasına ve ilaç direncine yol açarlar. Osteosarkom hücrelerinde, genlerde en sık görülen yapısal anomaliler 1p11-p13, 1q11-q12 ve 1q21q22'dir. Ayrıca 9, 10, 13 ve 17 numaralı kromozomların kaybı ve kromozom 1'de olan kazanımlar sık görülen anormalliklerdir. Ancak, hem hücreler arasında hem de tipler arasında kromozomal instabilite açısından homojenlik yoktur. ${ }^{[1-4]}$

\section{Klinik seyir}

Osteosarkomanın gradı, tedavi edilmeyen olgularda klinik seyri belirler. Yüksek gradlı lezyonlarda intramedüller başlayan tümör, hızla kortikal destrüksiyonla periost altına gelerek onu geçer, yumuşak doku kitlesinin oluşturur. Çevre yumuşak dokuları invaze ederek reaktif bir bölgede kendisini sınırlamaya çalışan lenfosit ve makrofajlardan zengin psödokapsülü de aşarak skip lezyonlar oluşturur. Kan damarlarını invaze ederek mikrometastazlarını akciğer ve iskeletin kalan bölümlerine yapar. Akciğer metastazı, kemik iliği inhibisyonu ve tümör toksemisi ile 3-6 ayda hastanın ölümüne yol açar. Düşük gradlı lezyonlar ise öncelikle lokal büyük tümör kitleleri oluşumuna ve sonra bölgesel lenf dügümlerine ve nihayet akciğer metastazına yol açarak ölüme yol açan nispeten yavaş bir seyir izler. Osteosarkom bu nedenle fatal bir hastalıktır ve yetkin bir şekilde tedavi edilmesi gerekir.

\section{Osteosarkomun Tedavisi}

Osteosarkomun yalnız cerrahi ile tedavi edildiği 1970 öncesi dönemde, ampütasyon ile tümörün vücuttan, bulunduğu ekstremite ile beraber uzaklaştırılmasına rağmen beş yıllık hastalıksız sağkalım \%10-15'lerde idi. Osteosarkomun tanısı konulduğunda, mikrometastazları yapmış olması ile ana ölüm 
nedeni akciğer metastazları idi. 1960'ların ikinci yarısında kemoterapinin gelişmesiyle ve medikal onkolojinin başlangıç dönemlerinde, solid tümörlerde sınırlı sayıda olguda denenen kemoterapinin istenen tümör kontrolünü ve uzak metastazların yok edilmesini sağlayamaması nedeniyle osteosarkomun kemoterapi ve radyoterapiye dirençli bir tümör olduğu kanısı hakimdi. Norman Jaffe, 1970'lerin başında metastazlı osteosarkomlarda yüksek doz metotreksatın etkin olduğunu, Gerry Rosen ise T-10 protokolü ile multimodal kemoterapinin etkinliğini adjuvant olarak gösterdiler. $^{[5-6]}$ Anestezi tekniklerinde gelişmeler, eklemi de kapsayan lokal kemik defektlerinin gerek ısmarlama ve sonra modüler tümör rezeksiyon protezleri ile rekonstrüksiyonundaki gelişmeler, kemik bankacılığının yaygınlaşması ile önce osteoartiküler, sonra kompozit allogreftler ile rekonstrüksiyon, mikrovasküler cerrahide gelişmeler ile serbest damarlı fibula ve miyokütan fleplerin nakli, geri kazanılmış kemik (otoklavize, irradiye, sıvı nitrojen ile muamele) tekniklerinin gelişmesi ile osteosarkomda lokal rezeksiyon ve rekonstrüksiyona dayanan ekstremite koruyucu cerrahi, geçmişteki ampütasyonların yerini büyük ölçüde almıştır. ${ }^{[7]}$

Son üç dekadda, osteosarkomun multidisipliner tedavi anlayışı gelişerek, neoadjuvant kemoterapi ve geniş eksizyonla tümörün çıkarılarak lokalizasyon ve yaşa göre protezle rekonstrüksiyon veya biyolojik rekonstrüksiyonla hem hayatı hemde ekstremiteyi korumak standart yaklaşım halini almıştır. Ampütasyon, ancak indüksiyon kemoterapisinde progrese olan, lokal radyoterapi eklense de canlıı̆ı̆ının koruyan olgularda, ihmal edilmiş eksülsere çok büyük tümörle başvuran olgularda ve lokal çıkarılması mümkün olmayan lokal nükslerin tedavisinde başvurulan bir yöntem haline gelmiştir.

Ekstremite koruyucu cerrahinin gelişmesinde en önemli katkı postmortem incelemelerle tümörün lokal biyolojik davranışının öğrenilmesi ve BT ile başlayan, MR ile devam eden kesitsel incelemelerle tümör ve etrafındaki reaktif bölge hakkında ayrıntılı bilgi edinilmesine dayanır. Kemik içinde iken intrakompartmantal olan klasik osteosarkom, ne yazık ki bu safhada yeterince şüphelenilmediğinden tanınmaz. Tümörün korteksi ve periostu aşıp yumuşak doku kitlesi oluşturmasından sonra, ekstrakompartmantal bir kitle olarak klinik bulgunun belirginleşmesi ile biyopsi sonucu tanısı kesinleşir.

Tümörün ekstraosseöz komponentinin çevresinde reaktif alanda tümör tomurcukları, skip metastazlar bulunması nedeni ile geçmişte yalnızca lokal rezeksiyon ile tedavi edilmeye çalışılan olgularda derhal erken lokal nüksler oluşmuştur. Bugün reaktif bölgenin sistemik kemoterapi ile sterilizasyonu ve tümör çevresinde nispeten bir psödokapsül gelişimi, fibrözis oluşumu, reaktif zonun indüksiyon kemoterapisinden sonra çekilen MR'lerinde kapsadığı alandan 1-2 cm uzaktan eksizyonu ile lokal rezeksiyonu takip eden lokal nüks oranları \%10 ve altına çekilmiştir. ${ }^{[8]}$

Modern osteosarkom, tedavisi biyopsi ile tümörün kesin tanısı konulduktan sonra, multidisipliner tümör konseyinde olgunun tekrar değerlendirilmesi ile başlar. Tedavinin ilk aşaması kemoterapidir. Kemoterapi önceleri intraarteriyel olarak başlamış ise de sistemik çok ajanlı kemoterapinin lokal tümör kontrolü ve sağkalımda intraarteriyel uygulamaya eşdeğer olduğunun görülmesi ile sistemik intravenöz olarak uygulanmaktadır. İntraarteriyel uygulamanın lokal problemleri ve zorluğu nedeniyle bu uygulama bugün neredeyse bırakılmış gibidir.

Kemoterapide adriamisin, metotreksat, cisplatin, ifosfamid+Mesna, etoposid gibi ilaçlar, tedavinin uygulandığı merkezin seçimine göre oluşturulan protokollerle üç hafta ara ile üç kür olarak 9-12 haftada tamamlanan indüksiyon kemoterapisi yöntemiyle uygulanmaktadır. Kemoterapinin başlangıcında hastanın akciğer BT'si, 3-fazlı dinamik tüm vücut sintigrafisi ve PET ile uzak metastazlar ve skip lezyonlar, direkt iki yönlü grafi, tüm kemiği gösteren MR ve dinamik MR ile lokal tümör yayılımı belgelenmektedir. Bu tetkikler tümörün kemoterapi öncesi canlılığını ve kemoterapiye yanıtını karşılaştırmak için taban değerleri oluşturur.

İndüksiyon kemoterapisinin bitiminde lokal direkt grafi ile tümörde mineralizasyon artışı, MR'de kitlede büyümenin durması, nekroz gelişimi, gadolinium tutulumunun azalması ve klinik olarak ağrının geçmesi, şişliğin artmaması genel olarak indüksiyon kemoterapisine iyi yanıt olarak değerlendirilir. Ameliyat öncesi MR ile tümörün kemikte bittiği yerden $2 \mathrm{~cm}$, yumuşak dokularda $0,5-1 \mathrm{~cm}$ adalenin uzağından lokal rezeksiyon yapılarak tümörsüz geniş eksizyon sınırları belirlenir ve ameliyatta bu sınırların gerisinde kalmamaya özen gösterilir. Osteosarkomun lokal tedavisi cerrahidir. Ameliyatı yapacak cerrahın deneyimli ve yeterli onkolojik cerrahi bilgi birikimine sahip olması gerekir. Osteosarkom cerrahisi sporadik yapılacak bir cerrahi değildir. Kontamine sınır lokal nükse ve ampütasyonlara yol açabilir. ${ }^{[9]}$ Ekstremite koruyucu cerrahide ilk aşama biyopsi traktının ve tümörün tümörden arınmış sınırlarla lokal rezeksiyonudur. Sağlam cerrahi sınırlara ulaşabilmek için arter ve ven invazyonu, sinir invazyonu, eklem invazyonu, organ invazyonu varsa tüm bu yapılan rezeksiyon planına alınır. Oluşacak defektin ve feda edilen yapıların rekonstrüksiyonu önceden planlanır. Damar cerrahisi, sinir cerrahisi, mikrocerrahi, 
plastik cerrahi ve organ feda edilecekse (mesane, barsak vb.) üroloji, genel cerrahi disiplinlerinden yetkin üyeler ameliyat ekibine dahil edilir. Turnike altında yapılan rezeksiyonu takiben kanama kontrolü ve rekonstrüksiyon işlemlerine geçilir. Kemik defektlerinin rekonstrüksiyonu eklemin bir yüzünü oluşturan kayıplarda intraartiküler, eklem boşluğu invazyonu varsa ekstraartiküler geniş rezeksiyondan sonra hastanın yaşı, cerrahın tercihi, erken fonksiyonel bir ekstremitenin kazanımı gibi aktörler, ısmarlama veya modüler protezler ile veya geri kazanılmış kemik ve vaskülarize fibula, taze donmuş allogreft ve internal tespit cihazları (IM çivi, plak vida kombinasyonları) ile rekonstrükte edilir (Şekil 5). Özellikle diz çevresinde yumuşak doku örtümünde, proksimal tibia rezeksiyonlarında ekstansör mekanizma oluşturulması için gastroknemius rotasyon flebi, sartorius flebi gibi lokal flepler, gerektiğinde mikrovasküler latissimus dorsi flebi transferi gerekebilir. Kalça ve omuz eklem kapsülü rekonstrüksiyonunda prolene mesh, trevira tube gibi fibrözisle uyumlu rekonstrüksiyon gereksinimi akılda tutulmalıdır (Şekil 6). ${ }^{10]}$

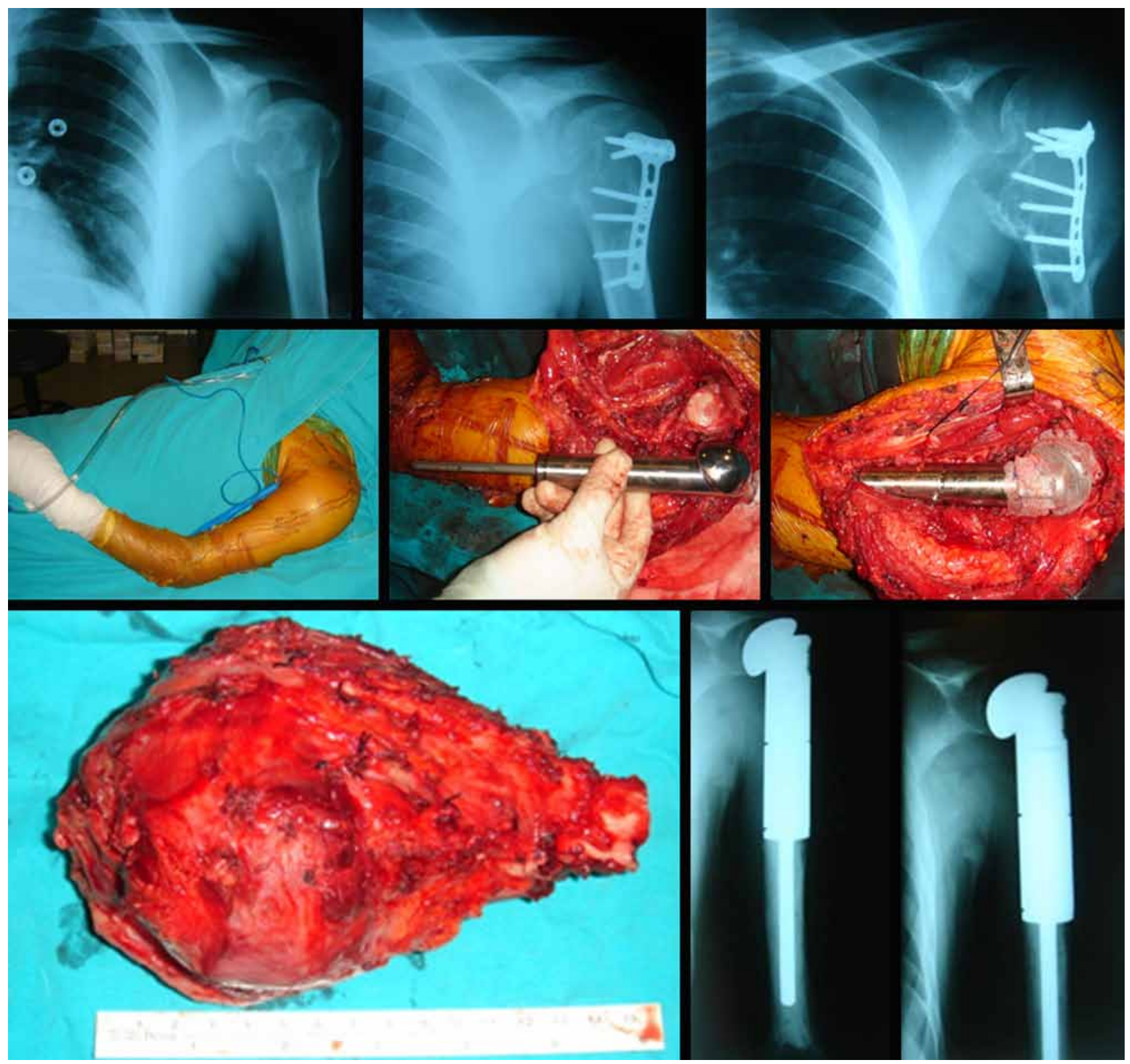

Şekil 5. Lokal rezeksiyon ve protez ile rekonstrüksiyon: O. B 17/E telenjektatik osteosarkom, patolojik kırık plak vida, lokal rezeksiyon, prolen mesh kapsül, deltoid kaybı. 


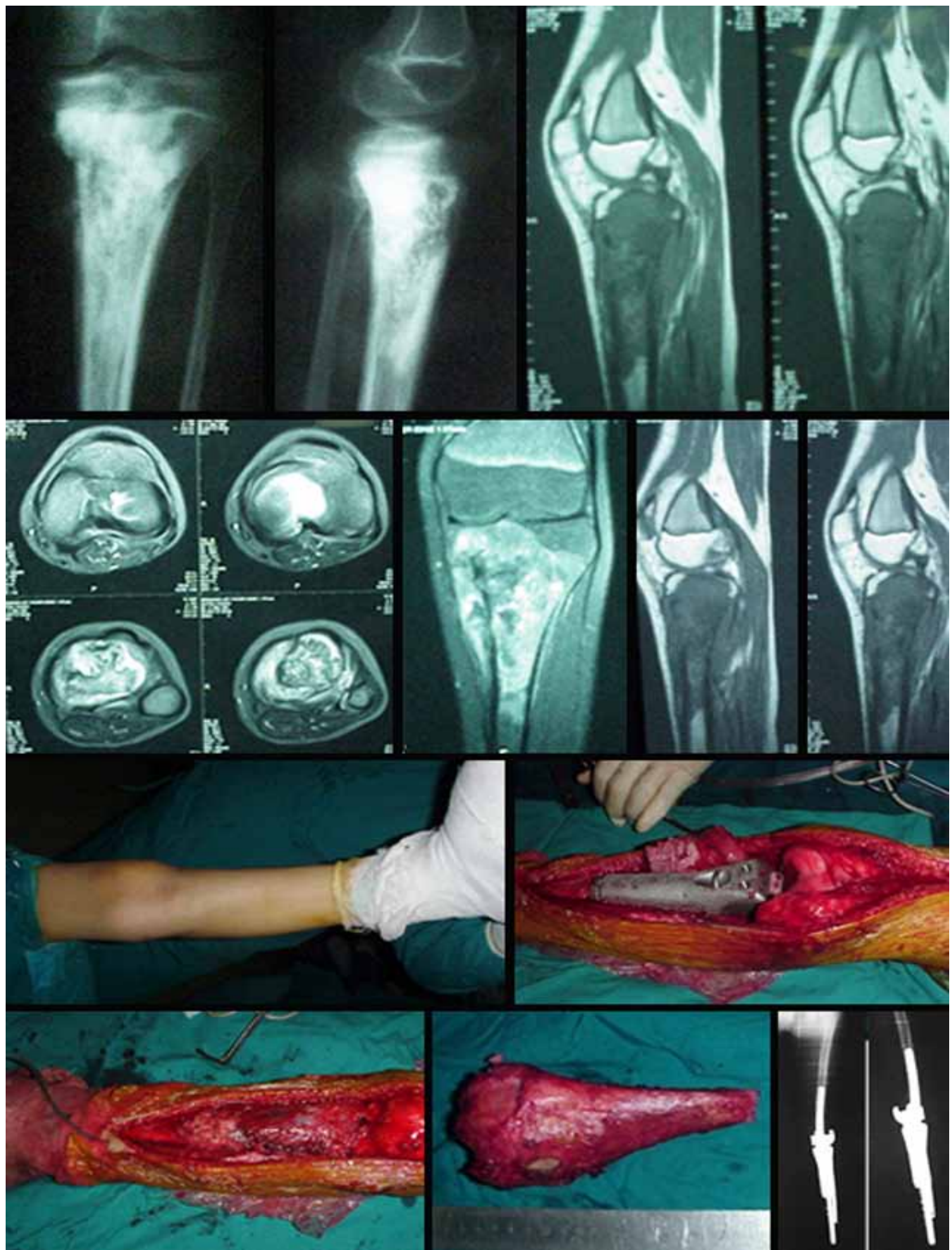

Şekil 6. Gastroknemius flebi: 14/K osteosarkom mediyal gastroknemius flep ile örtüm + çimentosuz protez. 
Protezle rekonstrüksiyon, derhal stabilite, erken fonksiyon kazanımı, modülarite gibi avantajlara sahiptir. Biyolojik rekonstrüksiyonlar ise başlangıçta erken yük verilmesine izin vermez iken uzun vadede dayanıklılık ve uzatmaya uyumlu rekonstrüksiyon olanağı verir. Zaman, protezin aleyhine, biyolojik rekonstrüksiyonun lehine çalışmaktadır. Ancak rekonstrüksiyon tercihinde dikkate alınması gereken en önemli hususlar, osteosarkomlu hasta profili ve sistemik tedavide alınması beklenen sonuçtur.

Bugün osteosarkomlarda hastalıksız beş yıl sağkalım oranları \%65 civarındadır. Diğer bir deyişle her üç osteosarkomlu hastanın biri 2-5 yıl içinde kaybedilmektedir. Lokal nüks oranları ekstremite koruyucu cerrahide \%10'un altındadır. Lokal nüks ve hastalıksız sağkalım üzerine etkin parametreler tümörün lokal rezeksiyonundan sonra histopatolojik olarak incelenen parçanın nekroz yüzdesi ve cerrahi sınırların geniş ve tümörsüz olmasıdır. Özellikle nekroz yüzdesini kemoterapiye tümörün yanıtını haritalama yöntemiyle belirlenir; \%90'ın üzerinde nekroz prognostik pozitif bir etmen olarak ortaya çıkmaktadır. Pozitif bir cerrahi sınır ise, özellikle kemoterapi sonucu nekrozun yüzdesi 90'dan düşük olduğu takdirde ampütasyonla telafi edilmelidir. Son on yılda, özellikle pediatrik grupta, epifiz plağını ve eklem yüzlerini korumak amacıyla yüzeyi hidroksiapatit kaplı Ismarlama protezler veya allogreft ve serbest fibula, geri kazanılmış kemik ve serbest fibula metodları ile rekonstrüksiyonu düşünülen metafizer rezeksiyonlarda kemoterapiye iyi yanıt verdiği düşünülen olgularda, tümörün reaktif bölgesine 1-2 mm'ye kadar yaklaşmak eğilimi göze çarpmakta ise de çimentosuz tespit yöntemleri ile noninvaziv büyüyebilen protezler diğer bir alternatifi oluşturmaktadır. Ameliyat sonrasında osteosarkomda nekroz yüzdesi 90'dan fazla ise, aynı kemoterapi protokolü ameliyat sonrası birinci haftadan itibaren başlayarak üç kür daha devam ettirilmektedir. Nekroz yüzdesinin 90'dan az olduğu durumlarda, kemoterapi ajanlarında değişiklik yapan (örneğin; yüksek doz metotreksat eklenmesi vb.) protokoller olmakla beraber genel eğilim, adriamisin, cisplatin ağırlıklı olarak devam etmektir. [7] Osteosarkomun cerrahi tedavisi esnasında pre-, peri- ve postoperatif dönemler, anestezi uygulaması ve yoğun bakım desteği, kan kaybının yerine konması ve tromboflebit profilaksisi önem arz eder.

Osteosarkomlu hasta immünosupresif etkiler nedeniyle normal ortopedi ve travmatoloji ameliyat adayı olgularından farklılıklar gösterir. Ameliyat öncesinde minimum \%35 hct, $10 \mathrm{gr} / \mathrm{dl}$ hgb, 120 000/ $\mathrm{mm}^{3}$ trombosit, $3000 / \mathrm{mm}^{3}$ lökosit normal aptt, pt, INR değerlerine erişmiş olması gerekir. Ayrıca böbrek, karaciğer fonksiyonları, kardiyolojik durum, laboratuvar testleri, elektrokardiyografi (EKG) ve ekokardiyografi (EKO) ile değerlendirilir. Anestezinin masif kan kayıplarına karşı deneyimli olması, yeterli izogrup eritrosit süspansiyonu ve taze donmuş plazma stoğunun sağlanmış olması gerekir. Hasta ve ailesinin, ameliyat, olası erken ve geç komplikasyonlar ile 1-2 gün yoğun bakım desteği olasılığı açılarından bilgilendirilmesi gerekir.

Osteosarkom tedavisinde olası komplikasyonlar; lokal nüks, sistemik metastaz, erken ve geç enfeksiyon ve rezeksiyona bağlı olarak ekstremite kısalığı ile rekonstrüksiyon tipine bağlı olarak protezlerde aseptik gevşeme, yorgunluk kırı̆g, hareketli polietilen parçalarda aşınma, patolojik kırık gibi ciddi komplikasyonlardır.

Osteosarkomun cerrahi tedavisini üstlenen ekip, olası komplikasyonlarla başa çıkabilme ve gerektiğinde uzun takiplerde revizyonları yapabilme yetenek ve azminde olmalıdır. Masif tümör protezleri veya allogreft ve geri kazanılmış kemiklerle yapılan rekonstrüksiyonlarda, özellikle enfeksiyon \%10-20 civarında benzer oranlara sahip ciddi bir problem oluşturmaktadır. ${ }^{[11]}$ Özellikle kemoterapinin devamı, nötrofil supresyonu ve beslenme sorunları, onkolojik hastalarda enfeksiyon yatkınlığına yol açmaktadır (Şekil 7).

Ameliyathane disiplini ve ortam temizliği, ameliyatta az travmatik, nazik manipülasyon, yeterli yumuşak doku örtümü, granülosit-koloni stimüle eden faktör (G-CSF) gibi nötrofil yapımını uyaran destek tedavileri, ölü boşluk bırakılmaması, yetereli cilt örtünümü, uzatılmış intravenöz (IV) antibiyotik profilaksisi, aspiratif dren tekniği enfeksiyonu azaltmada etkilidir. Erken ameliyat sonrası enfeksiyonlarda lavaj, debridman ve kültüre uygun antibiyotik, geç enfeksiyonlarda ise iki seanslı antibiyotikli cement spacer ve iki seansta yüzeyi enfeksiyona dirençli gümüş veya iyot kaplamalı protezler gerekeceği akılda tutulmalıdır. Titanyum protezlerin yüzeyine gümüş gibi bakterisit kaplamalar umut verici olmakla beraber henüz rutin kullanıma girmemiştir. ${ }^{[12]}$

\section{Osteosarkomlu hastanın takibi}

Kemoterapinin bitiminden itibaren hasta ortopedi ve medikal onkoloji polikliniklerinde ilk iki yıl üçer ay, sonraki üç yıl dörder ay, beşinci yıldan sonra altı ay arayla ve on yıldan sonra yıllık olarak takipte tutulur. Klinik muayene, direkt grafi, akciğer BT'si, tüm vücut kemik sintigrafisi ile özellikle ilk iki yıl lokal nüks ve sistemik metastazlar açısından izlenir.

Akciğer metastazları genellikle ikinci yıla doğru tepe yapar. Başlangıçta akciğer metastazı ile başvuran 

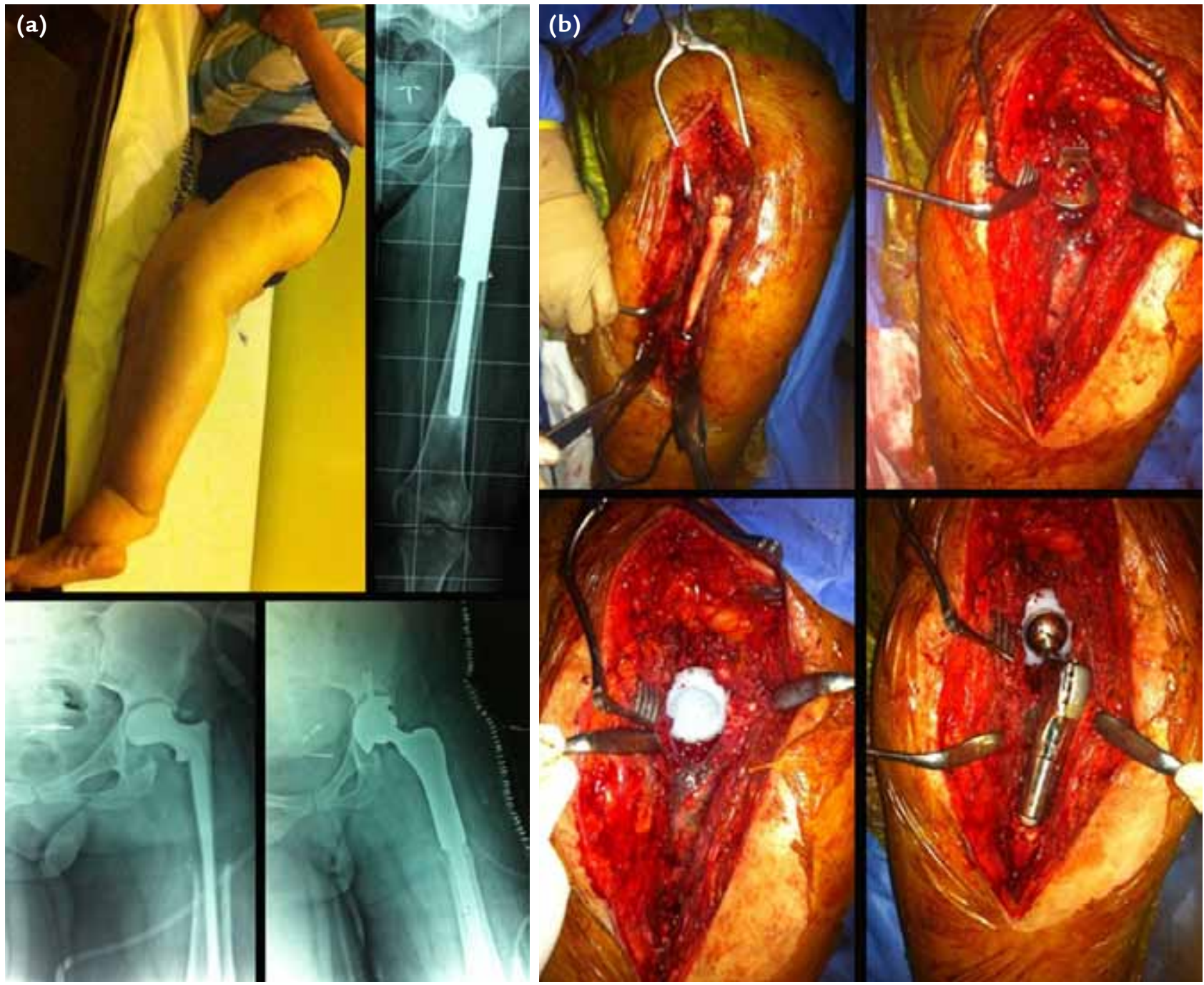

Şekil 7. a, b. İki seanslı enfekte protez revizyonu: $35 / \mathrm{K}$ sol proksimal femur osteosarkom (a), ameliyat sonrası 17 . yıl geç enfeksiyon, iki seanslı revizyon (b).

olgularda ameliyat sonrası kemoterapinin bitimini takiben metastazektomi ile kalan nodüller temizlenir. Takipte akciğer metastazı geliştiren olgularda ise lezyon adedine bağlı olarak üç kür salvage kemoterapisini takiben metastazektomi uygulanmaktadır. Metastazektomi uygulanan olgularda beş yıllık sağkaIım \%30 civarındadır.

Çok merkezli uluslararası uzun takipli osteosarkom serilerinden çıkan sonuca göre, osteosarkom tedavisinde neoadjuvant kemoterapinin ve ekstremite koruyucu cerrahi ile bir platoya eriştiği ve üç hastadan ikisinin beş yıl hastalıksız sağ ve fonksiyonel tutulabildiği gerçeğine varılmıştır. Bugünkü tedavi stratejisi nedene değil sonuca yönelik bir tedavi stratejisi olup, gelecekte hedefe yönelik yan etkisi düşük kemoterapi ajanlarının geliştirilmesi ve osteosarkom etiyolojisinin çözülmesi zorunluluğu mevcut başarıyı daha ileri götürecektir.

Osteosarkomda, erken teşhis, küçük tümör volümü, yeterli tedavi, tümörsüz cerrahi sınır ve fonksiyonel rekonstrüksiyon, lokal nüksün önlenmesi başarıyı arttıran etmenlerdir. Nadir görülen bu tümörün yeterli bilgi birikimine sahip, alt yapısı ve tümör konseyi oluşmuş merkezlerde tedavisi bir zorunluluktur. Ülkemiz sosyal güvenlik düzeyi ve yetkin kurumları ile bugün osteosarkomun çağdaş tıp düzeyinde tedavi edilebildiği ülkelerden biridir. Ancak, araştırma ve geliştirme faaliyetlerine önem vermek gereği de vurgulanmalıdır. 


\section{Sekonder Osteosarkomların Tedavisi}

Paget hastalığı, fibröz displazi, kemik infarktı zemininden çıkan sekonder osteosarkomlar yüksek gradlı habis tümörler olup tedavileri primer osteosarkom gibi yapılır. Nadir görülen bu olguların doğal davranışı primer osteosarkoma benzerve EMSOS (European MusculoSkeletal Oncology Society) araştırmalarında hayatta sağkalım açısından beş yıllık sağkalım \%50 civarındadır. Özellikle predispozan etmene sahip bu olgulara, 4-5. dekadda oluşan ağrılı şişliklerle hekime başvurmaları durumunda, sekonder osteosarkom gelişimi hakkında yeterli ön bilgi bu ilk başvurularında verilmelidir.

\section{Düşük gradlı osteosarkomların tedavisi}

Parosteal sarkom ve düşük gradlı intramedüller osteosarkom gibi osteosarkom tipleri kemoterapiye dirençli tümörler olduklarından, primer tedavi modalitesi geniş lokal rezeksiyondur. Bu nedenle, cerrahi sınırdan taviz vermeyerek, tümörlü bölge 1-2 cm kemik sınırı ile beraber eksize edilerek eksentrik rezeksiyonlarda otogreft veya allogreftle korteks rekonstrüksiyonu, segmenter defektlerde allogreft ile rekonstrüksiyon veya segment kaydırma yöntemleri, ekleme yakın komşuluk veya yaygın medüller infiltrasyon varsa epifizometafizer geniş eksizyon ve tümör rezeksiyon protezi ile rekonstrüksiyon tercih edilebilir.

\section{Aksiyel iskelette lokalize osteosarkomların tedavisi}

Vertebra ve pelvis yerleşimli osteosarkomlar nadir görülürler. Genellikle klasik yüksek gradlı osteosarkomlardır. Appendiküler iskelette yerleşmiş osteosarkomlar gibi indüksiyon kemoterapisi ve geniş rezeksiyon ile tedavi edilirler. İnternal hemipelvektomi, periasetabuler rezeksiyon ve rekonstrüksiyonlar ile yeterli cerrahi sınır sağlanabilir. Omurga tutulumunda enblok total vertebrektomi yapılabilirse de negatif cerrahi sınır elde edilmesi zordur. Anterior vertebra protezleri cage ve posterior stabilizasyon ile rekonstrüksiyonu sağlanabilir. Cerrahi uygulanamayan durumlarda lokal tedavi olarak radyoterapi definitif 5-7 Gy dozunda uygulanabilir. Proton tedavisi ve karbon iyon radyoterapisi umut verir görünmektedir. Aksiyel tutulumlu olgularda multidisipliner tedaviye rağmen beş yıllık sağkalım \%30'un altında ve lokal nüks oranı \%40-50 düzeyindedir.

\section{MALIGN FIBRÖZ HISTIYOSITOM}

Malign fibröz histiyositom (MFH), kemiğin nadir görülen kollajen üreten indiferansiye iğsi hücrelerden oluşan yüksek gradeli habis bir tümörüdür. ${ }^{[13]}$ Primer habis kemik tümörlerinin \%5'ini oluşturur. Erkek/kadın oranı 3:2'dir. ${ }^{[14]}$ En sık 3-4. dekadda görülür. En sık uzun kemiklerin epifizo-metafizer bölgesini tutar. Distal femur, proksimal tibia ve proksimal humerus sık tutulan lokalizasyon yerleridir; ancak, her kemikte görülebilir. Primer veya fibröz displazi, kemik infarktı osteomiyeliti, radyasyon zemininde gelişen sekonder olabilir.

\section{Klinik bulgular}

Özellikle diz çevresi gibi majör bir ekleme komşu ağrılı bir şişlik mevcuttur. Semptomlar genellikle 1-2 aydir mevcuttur. ${ }^{[14]}$

\section{Radyolojik özellikler}

Direkt grafide, özellikle de uzun kemiklerin metafizoepifizer bölgesinde eksentrik yerleşimle permeatif korteks destrüksiyonu yapan, ancak çoğunlukla periosteal reaksiyon oluşturmayan, litik destrüktif radyolüsent bir lezyon olarak görünür. Manyetik rezonans (MR) görüntülemede T1 hipointens T2 hiperintens tutulum gösteren, gadolinyum tutan bir lezyon olarak görülür. MR'de MFH'yi belirleyen bir özellik yoktur, ancak kemik içi ve kemik dışı yayılım ve damar-sinir yayılımı ile ilişki konusunda değerli bilgiler verir. Kemik harabiyeti bilgisayarlı tomografi (BT) ile direkt grafiye nazaran daha etkin değerlendirilebilir. Patolojik kırık görülebilir. Sekonder MFH'de ise altta yatan hastalık fibröz displazi, osteomiyelit, kemik infarktı veya radyasyon osteiti bulguları dikkat çekebilir. Tümörde mineralizasyon genellikle yoktur ve periost reaksiyonu olguların ancak \%38'inde görülür (Şekil 8). ${ }^{[13]}$

\section{Tanı}

Tanı, biyopsi ile konur. BT veya skopi eşliğinde trucut biyopsi, deneyimli patologların elinde yüksek tanı değerine sahiptir. Fibroblasta benzeyen atipik iğsi hücreler ve histiyosite benzeyen hücrelerle, kollajen yapımı gösteren yüksek gradeli indiferansiye pleomorfik bir sarkom olarak görülür. Reaktif dev hücreler ve 10 büyük büyütmede 5-10 mitoz görülebilir. ${ }^{[13]}$

\section{Tedavi}

Klinik davranışı osteosarkomaya benzeyen kemiğin MFH'si osteosarkom gibi tedavi edilir. Lokal geniş eksizyon ve adjuvant kemoterapi günümüzde yerini neo-adjuvant kemoterapi ve ekstremite koruyucu cerrahiye bırakmıştır. ${ }^{[15]}$ Radyoterapi, kontamine cerrahi sınır veya düşük nekroz oranında lokal tedaviye eklenebilir. Indüksiyon kemoterapisine yanıt osteosarkomdan düşüktür. Büyük serilerde $\% 90$ 'dan büyük nekroz olgularının ancak \%50'sinde görülmektedir. Beş yıllık hastalıksız sağkalım \%45-50 civarındadır. Akciğer metastazlarında metastazektomi önerilmektedir. ${ }^{[16]}$ 


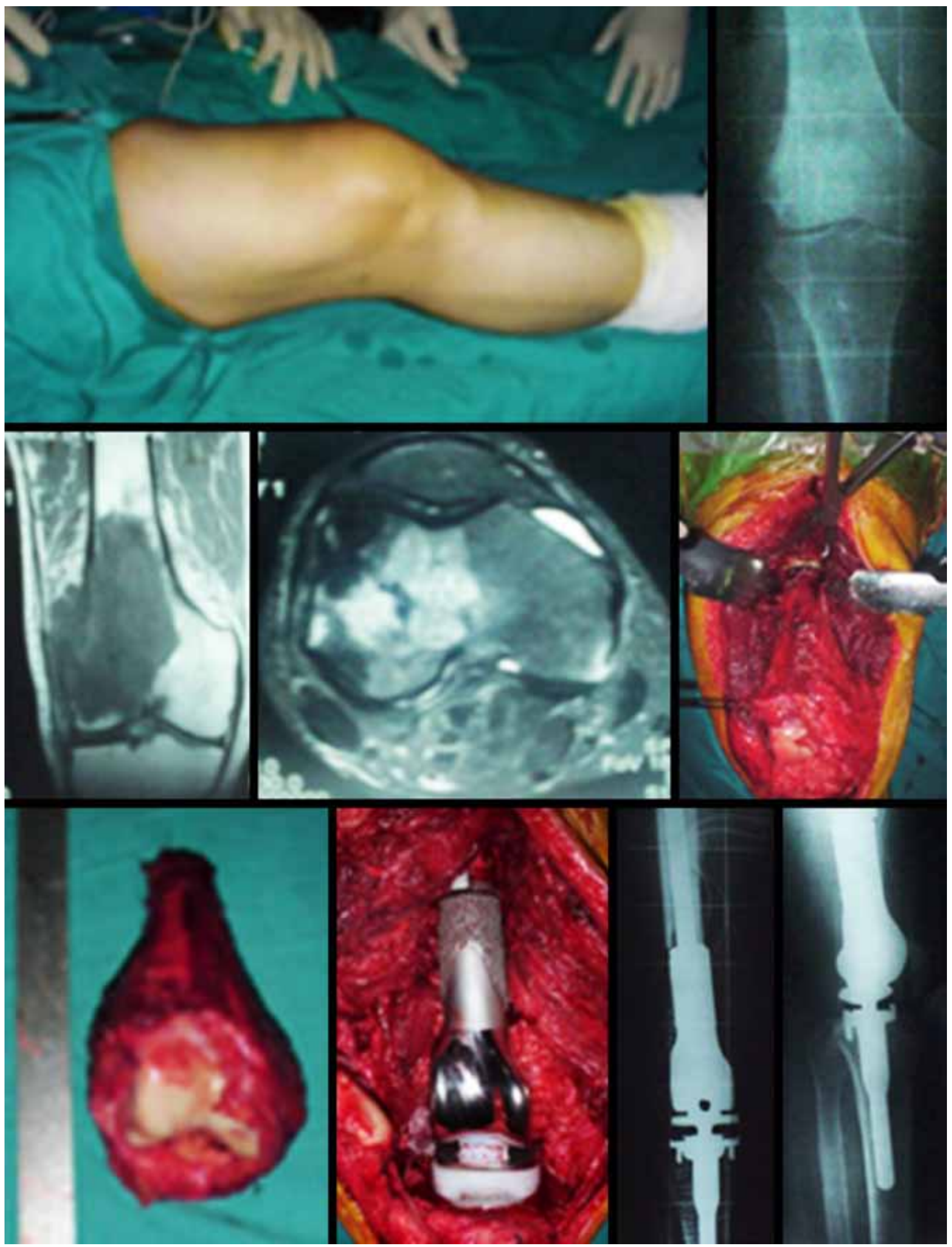

Şekil 8. 45/E, MFH, geniş eksizyon + protez. 


\section{KAYNAKLAR}

1. Mirra JM. Malignant Bone Tumours. In: Mirra JM, Picci $\mathrm{P}$, Gold RH. Bone Tumours: Clinical, Radiologic, and Pathologic Correlations, Philadelphia: Lea and Febiger; 1989. p.248-389.

2. Greanspan A, Jundt G, Remagen W. Differential Diagnosis in Orthopaedic Oncology. Bone Forming (Osteogenic) Lesions. 2nd ed. Philadelphia: Lippincott Williams \& Wilkins; 2007. p.88-9.

3. Briccoli A, Rocca M, Salone M, Guzzadella GA, Balladelli A, Bacci G. High grade osteosarcoma of the extremities metastatic to the lung: long term results in 323 patients treated combining surgery and chemotheraphy, 19852005. Surg Oncol 2010;19(4):193-9. doi: 10.1016/j. suronc.2009.05.002

4. Sandberg AA, Bridge JA. Updates on the cytogenetics and molecular genetics of bone and soft tissue tumours: osteosarcoma and related tumours. Cancer Genet Cytogenet 2003;145(1):1-30.

5. JaffeN, Carrasco H, Raymond K, Ayala A, Eftekhari F. Can cure in patients with osteosarcoma be achieved exclusively with chemotheraphy and abrogation of surgery? Cancer 2002;95(10):2202-10.

6. Rosen G, Huvos AG, Marcove R, Nirenberg A. Telangiectatic osteogenic sarcoma. Improved survival with combination chemotheraphy. Clin Orthop Relat Res 1986;(207):164-73.

7. Ando K, Heyman MF, Stresing V, Mori K, Rédini F, Heymann D. Current therapeutic strategies and noval approaches in osteosarcoma. Cancers (Basel) 2013;5(2):591-636. doi: 10.3390/cancers5020591

8. Springfield DS, Schmidt R, Graham-Pole J, Marcus RB Jr, Spainer SS, Enneking WF. Surgical treatment for osteosarcoma. J Bone Joint Surg Am 1988;70(8):1124-30.
9. Picci P, Sangiorgi L, Bahawonde L, Aluigi P, Bibiloni J, Zavatta M, Mercuri M, Briccoli A, Campanacci M. Risk factors for local recurrence after limb-salvage surgery for high-grade osteosarcoma of the extremities. Ann Oncol 1997;8(9):899-903.

10 Grimer RJ. Surgical options for children with osteosarcoma. Lancet Oncol 2005;6(2):85-92.

11. Mankin HJ, Gebhardt MC, Jennings LC, Springfield DS, Tomford WW. Long-term results of allograft replacement in the management of bone tumours. Clin Orthop Relat Res 1996;(324):86-97.

12. Jeys LM, Grimer RJ, Carter SR, Tillman RM. Periprosthetic infections in patients treated for an orthopaedic oncological condition. J Bone Joint Surg Am 2005;87(4):842-9.

13. Greanspan A, Jundt G, Remagen W. Differential Diagnosis in Orthopaedic Oncology. Bone Forming (Osteogenic) Lesions. Chapter 4. 2nd ed. Philadelphia: Lippincott Williams \& Wilkins; 2007. p.297-305.

14. Romeo S, Bovée JV, Kroon HM, Tirabosco R, Natali C, Zanatta L, Sciot R, Mertens F, Athanasou N, Alberghini M, Szuhai K, Hogendoorn PC, Dei Tos AP. Malignant fibrous histiocytoma and fibrosarcoma of bone: a re-assessment in the light of currently employed morphological, immunohistochemical and molecular approaches. Virchows Arch 2012;461(5):56170. CrossRef

15. Bramwell VH, Steward WP, Nooij M, Whelan J, Craft AW, Grimer RJ, Taminau AH, Cannon SR, Malcolm AJ, Hogendoorn PC, Uscinska B, Kirkpatrick AL, Machin D, Van Glabbeke MM. Neoadjuvant chemotheraphy with doxorubicin and cisplatin in malignant fibrous histiocytoma of bone: A European Osteosarcoma Intergoup study. J Clin Oncol 1999;17(10):3260-9.

16. Teng $\mathrm{H}$, Xinghai $\mathrm{Y}$, Wei $\mathrm{H}$, Huang $\mathrm{Q}$, Xiao J, Zhang $\mathrm{C}$. Malignant fibrous histiocytoma of the spine: a series of 13 clinical case reports and review of 17 published cases. Spine (Phila Pa 1976) 2011;36(22): E1453-62. 